\title{
Effectiveness of Financial Inclusion in Economic Growth of India
}

\author{
Sirangi Chandra Shekhar, Jothiselvamuthukumar
}

\begin{abstract}
Financial Inclusion (FI) is a significant interaction to accomplish the objective of comprehensive development. Appropriately, the Reserve Bank of India (RBI) has put forth, supported attempts to expand the entrance of basic financial services in unbanked zones, while proceeding with its strategy of guaranteeing satisfactory however feasible progression of credit to need areas of the economy. FI is conveyance of banking administrations at a reasonable cost to the immense segments of oppressed and low-pay gatherings. By FI we mean the arrangement of reasonable financial services, to be specific admittance to installments and settlement offices, investment funds, advances, and protection services by the formal framework to the individuals who are generally not offered these kinds of services by any other financial institutions due to their poor credit history. Meaning of FI emerges from the issue of financial exclusion of almost 3 billion individuals from the basic financial services across the world, with just 34percent populace occupied with formal banking. India has, 135 million FI families, the second most noteworthy after china. The current paper is a modest endeavor to discover the reasons for financial exclusion in India, examine the degree and extent of FI with regards to India and propose measures to take care of the issue of financial exclusion in India.
\end{abstract}

Key Words: Financial Inclusion (FI), Inclusive growth, Basic Financial Services, Financial Exclusion, Credit.

\section{INTRODUCTION}

$\mathrm{F}_{\text {inancial Inclusion (FI) is a significant cycle to }}$ accomplish the objective of comprehensive development. Likewise, the Reserve Bank of India has put forth supported attempts to build the entrance of basic financial services in unbanked regions, while proceeding with its approach of guaranteeing the sufficient yet feasible progression of credit to need areas of the economy. FI is the conveyance of banking administrations at a reasonable expense to the tremendous areas of oppressed and low-pay gatherings. By FI we mean the arrangement of reasonable monetary administrations, in particular admittance to installments and settlement offices, investment funds, credits, and protection administrations by the formal monetary framework to the individuals who will in general be rejected.

Manuscript received on March 09, 2021

Revised Manuscript received on March 15, 2021

* Correspondence Author

Sirangi Chandra Shekhar, Assistant Professor, Shadan Institute of Computer Studies for Boys, Hyderabad (Telangana), India.

Dr. A. Jothiselvamuthukumar, Assistant Professor \& Research Supervisor, Department of Business Administration, Annamalai University, Chidambaram (Tamil Nadu), India.

The Authors. Published by Blue Eyes Intelligence Engineering and Sciences Publication (BEIESP). This is an open access article under the CC BY-NC-ND license (http://creativecommons.org/licenses/by-nc-nd/4.0/)
Manuscript published on March 30, 2021.

In the Indian setting, the Rangarajan council characterizes FI as the way toward guaranteeing admittance to basic financial services and convenient and sufficient credit where required by weak gatherings at a reasonable expense. So, as indicated by this panel FI is the opportune conveyance of financial services to distraught segments of society.

The overall condition of monetary consideration is given by $\mathrm{FI}=\mathrm{NFA}+\mathrm{BC}$ Where, $\mathrm{NFA}=\mathrm{No}$ ruffles saving ledgers with least or zero equilibrium. $\mathrm{BC}=$ Business reporters which incorporate other monetary establishments (OFIs) like insurance agencies, common assets, annuity organizations, and so forth miniature monetary foundations (MFIs), and Information innovation (IT). Along these lines BC=Banks + OFIs +MFI+IT

\section{REVIEW OF LITERATURE}

Thapar (2013) contemplated the means are adopted and various strategies embraced by the business banks nearby monetary incorporation and the plans of RBI on Financial Inclusion. The examination reasoned that however the banks are consenting to RBI standards as far as opening branches inside zones of at any rate 2000 populace, offering no nonsense record, Kisan charge card, improving on KYC standards, actually is a ton of exertion to be placed in for monetary consideration progress. Banks need to open more branches inside country zones and making more mindfulness about financial administrations. Monetary incorporation requires endeavors on the pieces of three gatherings RBI, every one of the banks just as the overall population for its better advancement.

Sharma and Kucera (2012) have investigated the current status of monetary incorporation in the Indian economy and investigate the need and meaning of monetary consideration for the financial and social advancement of society. It was tracked down that that almost $50 \%$ of the Indian populace does not approach formal monetary administrations and is to a great extent reliant on cash loan specialists. The simple opening of no-ornament ledgers isn't the reason or the finish of monetary incorporation while formal monetary foundations should acquire the trust and altruism of the poor through creating solid linkages with local area based monetary endeavors and cooperatives. Joshi (2013) analyzed that the current arrangement objective of comprehensive development with monetary steadiness can't be accomplished without guaranteeing general monetary consideration and monetary incorporation can't be accomplished without the dynamic contribution of all partners like RBI, other monetary controllers, banks, governments, NGOs, common social orders, and so forth Monetary consideration doesn't simply mean credit for beneficial and $H_{4} / m_{\text {purposes; }}$ 


\section{Effectiveness of Financial Inclusion in Economic Growth of India}

it implies credit for medical services crises or to pay uneven school or school expenses, safe methods for compensated investment funds, and a simple method to make installments and settlements, protection, and benefits. It additionally incorporates monetary proficiency and buyer assurance.

Balamurugan, Karthikeyan, and Devi (2013) examined the current status of Financial Inclusion in India and found that it isn't just a socio-political goal yet in addition a monetary one. Monetary administrations are critical for neediness mitigation and improvement. To accomplish the objective of all out monetary incorporation, policymakers, MFIs, NGOs, and controllers need to cooperate. The previous 40 years tremendous framework has been grown yet insufficient, work should be finished by RBI and government on the grounds that most significant main impetuses of development is institutional money.

Sinha (2012) broke down monetary incorporation programs and the job of cooperatives in taking forward the goals of monetary consideration of comprehensive development with monetary strength and found that it can't be accomplished without monetary consideration. Banks need to see Financial Inclusion as a beneficial plan of action and not as a commitment. This would be conceivable just if banks endeavor towards offering increasingly more credit items to clients caught as a component of the Financial Inclusion Plan and lower exchange costs by utilizing innovation. Monetary consideration will go about as a wellspring of strengthening and permit individuals to take an interest all the more adequately in the financial and social cycle.

Dittos and Klein (2011) considered versatile cash or branchless financial plans across the world, the danger related to this sort of business models and their guideline. They reasoned that guideline ought to be planned by sort of administration and guideline should consider fundamental measurements. Subsequently the idea of the assistance should be breaking down, and the guideline be adjusted by the nature and dangers of the monetary help. Better monetary administrations help poor people cope better with the regular dangers of extortion and burglary.

Ice and Sullivan (2009) The size of the unbanked and underserved populace is excessively huge and spread across excessively huge of geologies to be appropriately served by ordinary channels alone. The Business Correspondent (BC) model, whereby specialists addressing banks, Micro-account Institutions (MFIs) or self-improvement gathering convey „doorstep bankingee is the most powerful model today supporting the government's drive towards Financial Inclusion. Enhancing the BC model with innovation can improve security, accelerate enrolments and exchanges, and expand the size of the actual domain that specialists can cover. Once the unbanked are gotten tied up with the financial model, an entire scope of monetary administrations can be conveyed through self-administration innovation, with insignificant requirement for individual to-individual communication.

\section{OBJECTIVES}

1. To uncover the reasons behind financial exclusion (FE) in India.

2. To inspect and scrutinize magnitude of financial inclusion in the context of India.

Absence of basic financial services to the poor individuals and lack of interest for proper monetary items and administrations by individuals is a significant reason for $\mathrm{FE}$ in India. A few causes that are responsible for $\mathrm{FE}$ in India are as follows.

1. Issues related Gender: Access to credit is regularly restricted for ladies who don't have, or can't hold title to resources, for example, land and property or should look for male assurances to get.

2. Legitimate personality: The essential prerequisite for opening ledgers is character verification and witness. Absence of legitimate characters like personality card, driving permit, birth endorsements, or put down accounts frequently avoid ladies, ethnic minorities, outcasts, traveler laborers from getting to monetary administrations.

3. psychological and social hindrances: The rustic individuals and low-pay bunches feels that banks are not intrigued to investigate their matter which has prompted self-prohibition for such gatherings of individuals. Anyway, social and strict hindrances to banking have been seen in a portion of the nations like Pakistan, Bangladesh and England.

4. Restricted education: In India restricted proficiency especially, monetary proficiency that is essential arithmetic, business account abilities just as absence of seeing frequently requirement individuals to approach from monetary administrations.

5. Terms and conditions: Many individuals are not open to utilizing formal monetary administrations since they face challenges in getting language, different terms and conditions that accompany monetary administrations. The low-pay individuals don't comprehend monetary item, utilization, activity and the board of records. It has additionally been seen that the destitute individuals living in metropolitan and country regions don't use the monetary administrations that accessible on account of significant expense. For instance, to open a ledger in Cameroon, the store necessity is over 700dollars. While no base sums Bangladesh, Pakistan, Philippines to get an independen venture credit prepared requires over a month, while the by is just a day in Denmark. 6. Age factor: Banks typically offers monetary assistance to the working class and financially dynamic populace, frequently ignoring the plan of proper items for more seasoned or more youthful expected clients.

7. Supply factors: Such figures consider a monetary organization's standards for tolerating a customer, the expenses it charges for admittance to its administrations and its prerequisites (e.g., its danger appraisal methodology). These can lead a bank to deny any assistance to an individual and can go about as a solid obstacle to a potential customer looking for a specific monetary help. Supply factors include the geographic area of the organization, which in a few cases is an essential driver of monetary avoidance. 
Request side or conduct factors: Apart from the inventory side components, request side variables can likewise subvert buyers' eagerness to draw in with monetary administrations and capacity to make successful, educated decisions and choices. These elements have a critical bearing on the degree of monetary incorporation. A higher portion of populace beneath the neediness line brings about lower interest for monetary administrations as the poor might not have reserve funds to put as store in reserve funds banks.

Subsequently, low pay prompts low interest for monetary administrations, especially reserve funds items. Similarly, at low degrees of improvement, speculation movement might be low and subsequently, may prompt low interest for credit from banks and other formal monetary foundations. In any case, as destitution levels decay and families move into higher levels of pay, their penchant to save builds, which, thusly, prompts more appeal for monetary

V.

\section{EXTENT AND MAGNITUDE OF FINANCIAL INCLUSION IN INDIA}

Financial Inclusion (FI) with regards to India infers the arrangement of moderate monetary services, to be specific, admittance to installment and settlement offices, reserve funds, credits and protection administrations by the conventional framework to the individuals who will in general be avoided. In India, the term FI initially highlighted in 2005, when RBI, in its yearly approach articulation of 2005-06, while perceiving the worries as to the financial practices that will in general prohibit as opposed to pull in tremendous segments of the populace, encouraged banks to survey their current practices to adjust them to the goal of FI. Although the term FI was not vogue in India at that point, since the last part of the 1960s both the public authority and the RBI have been worried about the nonaccessibility of banking offices to the oppressed and more fragile segments of the general public. The public authority of India's National Rural Financial Industrial Plan (NRFIP) has set an objective to accomplish total monetary consideration by 2015. The arrangement means to serve 50 percent of the monetarily barred 280 million populace by 2012 through provincial and semi metropolitan parts of business and territorial rustic bank. In the Index of monetary incorporation arranged by the Indian gathering for research on International Economic Relations (ICRIER), India has been set 50th situation in the rundown of 100 nations. The list of monetary consideration, which measure the accessibility and use of ledgers per1000 grown-ups, number of ATMs and bank offices per million individuals and the measure of bank credits and stores. While monetary development in India has profited a developing working class, it has likewise made incredible incongruities among rustic and metropolitan zones, prosperous and slacking states, and between semi talented and low gifted laborers. The expansive technique for monetary incorporation in India lately involves the accompanying components.

1. Empowering entrance into unbanked and in reverse territories and empowering specialists and mediators like NGOs, MFIs, CSOs and business reporters (BCs)

2. zeroing in on a decentralized methodology by utilizing existing game plans like State Level Bankers' Committee
(SLBC) and area consultative board (DCC) and fortifying nearby foundations like co-agents and RRBs

3. Utilizing innovation for promoting FI

4. Encouraging banks to open a fundamental banking 'straight forward's record

5. Accentuation on monetary education and credit directing and

6. Making cooperative energies between the formal and casual fragments.

Different activities of monetary incorporation embraced could extensively be ordered into three stages.

1. 1970-1990: Channeling credit to the ignored areas and uncommon accentuation was laid on more fragile segments of the general public.

2. 1990-2005: The fundamental spotlight was chiefly on reinforcing the monetary area changes. In this stage monetary incorporation was energized essentially by the presentations of SHGs-bank linkage program in mid 1990s and Krishan Credit Cards (KCCs) for giving credit to ranchers. The SHGs-bank linkage program was dispatched by NABARD in 1992 with strategy support from the Reserve Bank, to encourage aggregate dynamic by poor people and gives entryway step banking.

3. 2005-onwards-In the third stage, monetary consideration was unequivocally made as a significant arrangement objective and push was on giving safe office of investment funds stores through "no nonsense" account.

Bank nationalization in India denoted a change in perspective in the focal point of banking as it was proposed to move the concentration from class banking to mass banking. The reasoning for making Regional Rural Banks was likewise to take the financial administrations to destitute individuals. The parts of business banks and the RRBs have expanded from 8,321 in the year 1969 to 68,282 branches as toward the finish of March 2005. The normal populace per branch office has diminished from 64,000 to 16,000 during a similar period. In the Indian setting, even after the execution of the new Branch Authorization Policy of Reserve Bank, out of a sum of 1,250 new branches that were opened during July 2004-June 2005 just $1.2 \%$ branches were really opened in the un-banked regions. During similar Corresponding period during 2005-06, 933 new branches were approved to work and out of which just $0.21 \%$ were opened in the un-banked regions.

\section{CURRENT SCENARIO OF FINANCIAL INCLUSION IN INDIA}

The present trend of FI in India reveals a significant variation across the states in the No. of accounts pre 100 of total population and per 100 of adult population, No. of banks, Primary Agricultural Credit societies in rural areas (PACs) in rural areas etc. A survey of 14 leading states of India in 2011 reveals that states such as Maharashtra, West Bengal, Punjab, Gujrat have reasonably high No. of financial inclusion, banks and Primary Agricultural Credit societies (PACs) in rural areas. For example, Maharashtra has 46 PACs per 100,000 persons while west Bengal has 38 banks. Again, other statistics collected from Indian institute of Banking and Finance on total No.

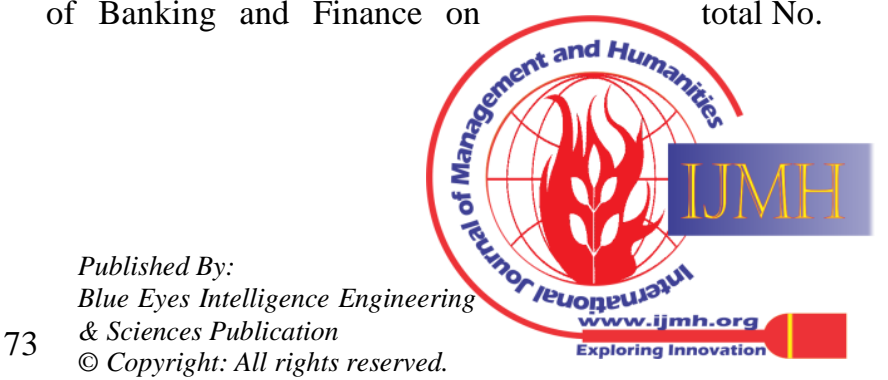




\section{Effectiveness of Financial Inclusion in Economic Growth of India}

of branches, total No. of rural branches, new rural branches etc. in India reveals a variation in the period 20102020 (Table-1). Out of the total 5165 new branches opened in 2011, only 21.86 percent are rural branches. Currently the No. of accounts per 100 of adult population and the total population in India is 59 and 31 respectively. According to the annual report (2010-2020) of CGAP and the World Bank the No. of deposit accounts per 100 adults for the period is 747.29 and the value of GDP is 55.03percent (Table-2). Similarly, according to the same report the No. of outreach total branches per 100,000adults in urban and rural area is equal to 3.82 and 6.29percent respectively for the period 2010-11.

This report gives highest importance of macroeconomic stability and growth for improving financial access. Now RBI is keen on achieving 100percent financial inclusion for sustaining equitable growth. To achieve the target of 100percent financial inclusion, however, 1584 million accounts will need to be opened. But despite the efforts taken by the government there exist a sharp financial exclusion in the country.

TABLE-1: RURAL BRANCHES IN INDIA

\begin{tabular}{|l|l|l|}
\hline Particulars & $\begin{array}{l}\text { March } \\
2010\end{array}$ & $\begin{array}{l}\text { March } \\
2020\end{array}$ \\
\hline Number of branches in total & 7005 & 75214 \\
\hline Rural area branches in total & 22435 & 22698 \\
\hline Urban area branches in total & 46753 & 51243 \\
\hline New branches in total & 3345 & 4597 \\
\hline New rural branches in total & 896 & 2341 \\
\hline New urban branches in total & 2345 & 5643 \\
\hline
\end{tabular}

Source: IIBF reports

\section{TABLE-2: FINANCIAL ACCESS: COMMERCIAL} BANKS (2009-10)

\begin{tabular}{|l|l|l|l|}
\hline $\begin{array}{l}\text { Financial } \\
\text { access }\end{array}$ & $\begin{array}{l}\text { Accounts } \\
\text { Per 1000 } \\
\text { adults }\end{array}$ & $\begin{array}{l}\text { Value } \\
\text { \%) of } \\
\text { GDP }\end{array}$ & $\begin{array}{l}\text { Average } \\
\text { account Value } \\
\text { \%of income } \\
\text { PC) }\end{array}$ \\
\hline Deposits & 747.29 & 55.03 & 107.86 \\
\hline Loans & 137.46 & 40.93 & 436.09 \\
\hline $\begin{array}{l}\text { Outreach } \\
\text { branches per } \\
\text { 100,00adults }\end{array}$ & $\begin{array}{l}3.82 \\
\text { (Urban) }\end{array}$ & $\begin{array}{l}6.29 \\
\text { (Rural) }\end{array}$ & 10.11 (Total) \\
\hline
\end{tabular}

Source: CGAP-World Bank

\section{SIGNIFICANCE OF THE STUDY}

Meaning of FI emerges from the issue of FE of almost 3billion individuals from the monetary administrations across the world, with just 34percent populace occupied with formal banking. India has, 135 million monetarily barred families, the second most noteworthy after china. Further the genuine pace of FI in India is low and about 40percent of the ledger holders utilize their records not even once per month. As indicated by appointee legislative head of R.B.I, K.C Chakraborty, there is a huge hole between the inclusion of banking administrations among the grown-up populace in metropolitan and rustic India. In provincial India, the inclusion among the grown-up populace is 39percent against 60percent in metropolitan India. Accordingly, notwithstanding far and wide development of the financial area, a huge extent (40percent) of the families particularly in rustic regions stays outside the inclusion of the proper financial framework. In India the monetarily barred segments include to a great extent rustic masses containing minimal ranchers, landless laborer's, independently employed and disorderly area undertakings, metropolitan ghetto occupants, socially avoided gatherings, senior residents and ladies. In India alone 560 million individuals avoided from formal wellspring of money. Monetary incorporation has arisen as an instrument for the financial advancement of society. The bushel of monetary administrations under monetary avoidance will set out a freedom for rustic individuals and in this manner driving the financial development of the country. The investigation of monetary incorporation is profoundly significant for the general public since results of monetary avoidance might be very unsafe. It might produce lower speculation coming about because of challenges in gaining admittance to credit or acquiring credit from casual area at exceptionally high loan costs. The significance of monetary consideration is likewise generally perceived in arrangement circles and has become a strategy need in numerous nations. A few imperatives across the globe currently view at monetary incorporation as the way to more complete development, where in every resident of the nation can utilize profit as a monetary asset that can be given something to do to improve future monetary status and adding to the country's advancement.

\section{CONCLUSION}

Evidences shows that economic development follows financial inclusion (FI). Boosting business openings will build the GDP, which will be reflected in our public pay development. Individuals will have safe investment funds alongside admittance to associated items and administrations, for example, protection cover, enterprising credits, installment and settlement office, and so on Publicprivate organizations can add to FI, with government offering the suitable administrative structure and motivating forces to specialist co-ops, and private administrators expanding their institutional effort and scope of administrations. Models that the financial area can use to extend monetary access incorporate retail banking, discount banking in organization with MFIs, and establishment or specialist banking. Microfinance "handling centers" an possibly give "back-end" innovation to the business and help specialist organizations in conquering cost leaps that are keeping down the development of monetary consideration. There is likewise a need to create associations, and to bring down expenses to build the openness of specific administrations for specific gatherings, for example, settlement administrations for traveler laborers. Our fantasy of comprehensive development won't be finished until we make a great many miniature business people the nation over. Microfinance can possibly enlarge monetary consideration by connecting the requirements and openings at the lower part of the financial pyramid and the assets of the monetary area. To summarize, FI is the street that India needs to go toward turning into a worldwide player. Monetary access will pull in worldwide market players to our country and that will bring about expanding work and business openings.

\section{Published By:}

Blue Eyes Intelligence Engineering \& Sciences Publication (C) Copyright: All rights reserved.

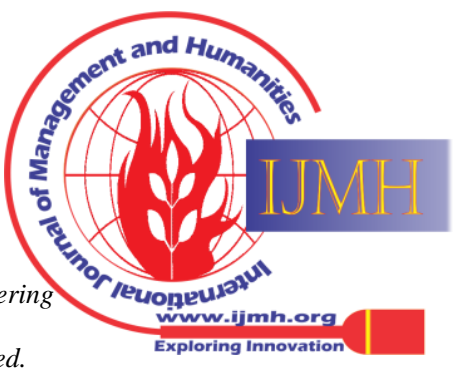




\section{REFERENCES}

1. H.M. Treasury, (2007): "Financial Inclusion: The Way Forward", HM Treasury, UK, March.

2. Kimpson, E. and C. Whyley (1999b) Understanding and combating financial exclusion. Insurance Trends, 21: 18-22.

3. Nathan, H.S.K., S. Mishra and B.S. Reddy (2008) An Alternative Approach to Measure HDI. IGIDR Working Paper WP-2008-002.

4. Rangarajan Committee (2008) Report of the Committee on Financial Inclusion. Government of India.

5. Samra M and J. Paris (2010) Financial Inclusion and Development, Journal of International Development, DOI: 10.1002/jid.1698.

6. Sinclair S. P. (2001). Financial exclusion: An introductory survey. Report of Centre for Research in Socially Inclusive Services, HeriotWatt University, Edinburgh.

7. Srinivasan, N (2007)" Policy Issues and role of Banking System in Financial Inclusion' EPW, Jul.28, p. 3091.

8. www.european-microfinance.org/ue-et-exclusion-financiere_en.php.

\section{AUTHOR PROFILE}

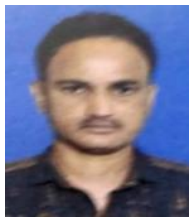

Sirangi Chandra Shekhar, Research Scholar, Department of Business Administration, Annamalai University, Chidambaram, TN. Assistant Professor, Shadan Institute of Computer Studies for Boys, Khairtabad, Hyderabad, TS.

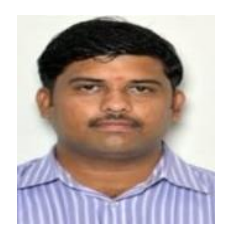

Dr. A. Jothiselvamuthukumar, Assistant Professor \& Research Supervisor, Department of Business Administration, Annamalai University, Chidambaram. Tamilnadu.

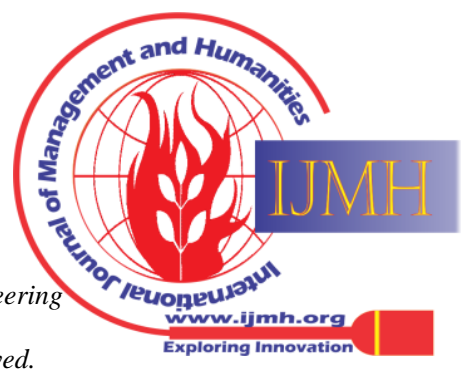

